\title{
THE RELATIONSHIP BETWEEN CONCORDANCE OF SOME PERSONALITY DIMENSIONS AND VISUAL EVOKED POTENTIALS
}

\author{
Sanja TATALOVIĆ VORKAPIĆ \\ Faculty of Teacher Education, University of Rijeka \\ University Avenue 6, 51000 Rijeka, Croatia \\ E-mail: sanjatv@ufri.hr
}

\begin{abstract}
This research is aimed to investigate the possible difference in ERPs between subjects with high and low concordance of nine personality dimensions: extraversion, neuroticism, psychoticism, strength of excitation, strength of inhibition, mobility, impulsiveness, adventurousness and empathy. Applying standard visual oddball paradigm in two blocks, early and late EP-components are measured: N1, P2, N2, P3 and SW in a sample of $\mathrm{N}=54$ psychology students (all females, averaged age of 20 years). Results showed significant difference in measured ERPs, except in slow wave. The low concordance group showed significantly lower EP-amplitudes and longer EP-latencies of N1, P2, N2 and P3. Also, significant correlation was determined between year of study and personality concordance, where students of higher years of study showed higher levels of concordance. The findings were discussed in the frame of an important relationship between evoked potentials and concordance of personality dimensions, in this case as a part of ongoing maturation processes.
\end{abstract}

Key words: concordance, personality dimensions, study year, visual evoked potentials

\section{INTRODUCTION}

The concept of personality dimensions' concordance level is relatively new and rare in the field of personality psychology. Very small number of studies have explored this concept specifically(Chernyshevetal., 2011). Nevertheless, it deserves to be explored for several reasons, especially in relation to its electrophysiological correlates. First of all, considering methodological requirements, correlation coefficients, present but not nec-

Acknowledgements: I would like to thank my colleagues I.E. Lazarev, D.M. Ramendik and B.V. Chernysahev for their valuable consultations on this paper. essarily very high, between different personality measures, which justify their construct validity, are to be expected. Consequently, data based on self-rated personality questionnaires stronglydemonstrated highly and significantlycorrelated results (Rusalov, 2000). This implies that it is reasonable and objective to expect correlated results on different personality questionnaires in a great number of people. It is reasonable to find certain combinations of temperament and/or personality features that form some standard patterns with cognitive, affective and behavioral specificities. Therefore, an individual who showed higher levels of strength of excitation, also manifested higher levels ofmobility of the central nervoussystem (Strelau etal., 1999), higher extraversion, relatively low emotional reactiv-

DOI: $10.21909 / \mathrm{sp} .2014 .04 .669$ 
ity, higher activity and endurance, higher sensory thresholds and stable attention (Eysenck, Eysenck, 1985).

On the other hand, even though there is a strong reason to expect highly correlated various personality and/or temperament dimensions, Ramendik (2008) determined that some individuals showed a strong discordance between results in personality questionnaires. Therefore, very similar to objective observations and analysis that was run in the fields of intelligence and cognition, where findings showed different levels of concordance between various IQ-subscales (Knight, 1997), some individuals show high and some low level of personality dimensions concordance. This fact is leading to the second reason for using this particular measure in this research. While there is considerable literature in the significance and clinical utility of VIQ-PIQ differences within application of WAIS (Lezak, 1994), there are only a few sources regarding the meaning of personality dimensions' concordance. For example, when one of the subscales falls in the low average or lower range, and the other in the average or higher range, this can indicate a certain neurological impairment. Therefore, following the significantly negative relationship between intrasubtest differences of commonly used IQ or/and cognitive efficacy measures and overall psychological functioning, it is reasonable to expect higher levels of personality dimensions' concordance in more mature and healthier individuals. With the aim of understanding the different personality dimensions' concordance levels, it is very important to explore all their possible correlates, especially electrophysiological ones.

Studies, which have explored temperament and/or personality dimensions in relation- ship with evoked brain potentials, are the only kind of studies that employed this particular personality measure (Chernyshev et al., 2011; Lazarev et al., 2012). This kind of start is a desirable one, since the possibility of determinating physiological correlates of the temperament structure could reveal the real meaning of personality dimensions' concordance. The utility of the application of the ERP-method (event-related potentialmethod) in personality studies has been confirmed in numerous studies (Polich, 1998; Tatalović Vorkapić, 2009, 2010). Electrophysiological studies that applied the ERP-method were able to provide useful data about brain correlates of numerous psychological processes, which have a time resolution much more precise than standard behavioral measures (Luck, 2005). After giving a stimulus in a certain modality (visual or audio), it is possible to measure brain activity from very early, non-cognitive potentials that deal only with physical characteristics of the stimuli, to middle and late EP-components, that are truly attentional and cognitive (Polich, 1993). Previous studies have investigated the heightened perceptual sensitivity in introverts, as predicted by the arousal theory. Results showed that higher extraversion was significantly correlated with lower P3-amplitudes (Beauducel, Brocke, Leue, 2006; Hansenne, 2000; Stelmack, Geen, 1992; Stenberg, Rosen, Risberg, 1990). However, the obtained effects have been significantly modified by psychological factors, such as attention and habituation, in a way that higher extraversion corresponded to a higher P3-amplitude (Gurrera, et al., 2005; Philipova, 2008; Stenberg, 1994; Tatalović Vorkapić, Tadinac, Rudež, 2011). In addition, ERPs showed to be significant electrophysiological correlates of temperament, measured 
within the Strelau temperament theory(1983), since significant positive correlations were determined between amplitudes of the N1P2-N2-P3 components and strength of excitation and mobility. Also, some studies found significant negative correlations of amplitudes of the N1-P2-N2-P3 components and strength of inhibition (Tatalović Vorkapić, Tadinac, Lučev, 2013).

Even though there are certain controversial findings due to different methods used for measuring conditions, different tasks utilized for evoking the ERPs, the habituation effect and various cognitive and noncognitive correlates that my moderate the personality-brain relationship, it is important to continue the investigation using different methodological approaches. Therefore, using these various personality and temperament theoretical backgrounds while examining human personality, it would be more than interesting to explore the concordance level between these individuality measures in relation to the ERPs. The previously mentioned Russian studies revealed that participants with high discordance in temperament dimensions presented a different picture of the relation between temperament and its physiological correlates, with a much less clear organization and manifestation. More concrete, "concordant" subjects showed significantly higher N2-P3 complex amplitudes. The authors assumed that in the "discordant" subjects' performance of the attention task recruited fewer brain resources than in the "concordant" people (Chernyshev et al., 2011; Lazarev et al., 2012).

So, the main aim of this study was to analyze the relationship between the concordance level of some personality dimensions and visual evoked potentials. The first prob- lem was to explore the relationship between different personality dimensions within two concordance groups (high and low) and their relationship with age and a year of study. Secondly, the relationship between different concordance levels of nine personality dimensions and visual evoked potentials was examined. The third problem was aimed to investigate the significance of the difference between high and low concordance groups in the measured EPs. For that purposes, Eysenck's personality theory and Pavlov's temperament theory have been used as a theoretical background in measuring various personality dimensions. On the other hand, searching for some electrophysiological correlates, visual evoked potentials have been measured. According to the previous research results, it was expected that certain differences in amplitude and latencies of visual evoked potentials between the groups of high and low concordance personality dimensions will appear.

\section{METHODS}

\section{Participants}

A sample of $\mathrm{N}=54$ psychology students (all female) participated in this study. Their average age was $\mathrm{M}=20.5$ years $(\mathrm{SD}=1.28)$ with a range between 19 and 23 years. They were all attending a four-year study program at the Department of Psychology, Faculty of Humanities and Social Studies, University of Rijeka in Croatia, as undergraduate psychology students. With the aim of reducing possible correlates of central variables, they were all right-handed and reported no visual and/or neurological/psychiatric problems. All subjects read and signed a written consent 
form stating that their participation in the study was totally voluntary, and they were informed that they will receive course credit for their participation. At the beginning of the research, students picked their own code-names, so the condition of anonymity could be ensured.

\section{Questionnaires and Concordance Groups}

Overall, nine personality dimensions were examined. Based on Eysenck' personality theory, two questionnaires were administered: Eysenck's Personality Questionnaire - the Revised version (EPQ-RA) and its standardized version (Eysenck, Eysenck, 1994), which was used for the purpose of measuring levels of extraversion, neuroticism and psychoticism. This instrument consisted of 106 items, on which subjects chose between YES and NO answers. Item analysis in this study confirmed earlier satisfactory levels of reliability: The following Cronbach Alpha values were recorded: 0.89 for extraversion, .89 for neuroticism and 0.61 for psychoticism. Also, Eysenck's Personality Questionnaire - Impulsivity, Venturesomeness and Empathy (EPQ-IVE) in its standardized version (Eysenck, Eysenck, 1994) was administered to measure levels of impulsivity, adventurousness and empathy. It consisted of 54 items on which subjects also chose between YES and NO answers. Item analysis also confirmed previous levels of reliability: Cronbach Alpha values were: 0.74 for impulsivity, 0.79 for the adventurousness scale, and 0.70 for empathy. In addition, Pavlov's theory of CNSdimensions' properties was measured by standardized Croatian version of Pavlov's Temperament Survey (Lučev, Tadinac, Tatalović, 2002), which measures Strength of Excitation (SE), Strength of Inhibition (SI) and Mobility (MO). The questionnaire consists of 69 items -23 items for each subscale. Subjects answered questions on 5-point Likert scale (from 1-totaly disagree to 5-totaly agree). Item analysis confirmed previous satisfactory levels of reliability of all three PTS scales: $\alpha=.86$ for SE; $\alpha=.78$ for SI and $\alpha=.89$ for $\mathrm{MO}$.

In order to create two groups of subjects (Group I and II), according to their concordance with the questionnaire results, we used the mean values of measured personality dimensions (M) and their standard deviations (SD). The value $\mathrm{X}$ of each participant's personality dimensions determined in this study was assigned to one of the three categories following these formulas: category with low level ( $\mathrm{X}<\mathrm{M}$-SD), category with medium level $(\mathrm{M}-\mathrm{SD}<\mathrm{X}<\mathrm{M}+\mathrm{SD})$ and category with high level $(\mathrm{X}>\mathrm{M}+\mathrm{SD})$. After that first categorization, the concordance match was checked for each personality dimension with respect to all other dimensions. Finally, Group I included those subjects who showed total concordance between the determined X values on personality dimensions or showed a difference in one personality dimension value. Therefore, the subjects who were categorized based on personality dimensions like this $\mathrm{e}=2, \mathrm{n}=2, \mathrm{p}=2, \mathrm{se}=2, \mathrm{si}=2, \mathrm{mo}=$ $2, \operatorname{imp}=2, \operatorname{adv}=2$, emp $=2$ (total concordance) or like this $\mathrm{e}=2, \mathrm{n}=2, \mathrm{p}=2, \mathrm{se}=2$, $\mathrm{si}=1, \mathrm{mo}=2, \mathrm{imp}=2, \mathrm{adv}=2, \mathrm{emp}=2$ (difference in one personality dimension) were included in Group I. All other subjects, with a difference in two or more $X$ value of personality dimensions were assigned to Group II. For example, a subject with the values of $\mathrm{e}=1, \mathrm{n}=3, \mathrm{p}=2, \mathrm{se}=1, \mathrm{si}=2, \mathrm{mo}=1$, $\operatorname{imp}=1, \mathrm{adv}=1, \mathrm{emp}=2$ would be in Group II. So, the categorization of concordance and 
discordance groups was done based on the subjects' match within three previously explained categories and not according to the correlation between their results on the personality measures. Since discordance in Group II could be related to various personality dimensions, this group might be heterogeneous. Accordingly, analysis showed that the concordance group - Group I consisted of $\mathrm{N}=13$ subjects and the discordance group - Group II consisted of $\mathrm{N}=41$ subjects.

\section{Visual Evoked Potentials - Measurement and Procedure}

After questionnaire completion, the subjects were informed about EP-measurement schedule at the Laboratory for Evoked Potentials of Department of Neurology at the Clinical Hospital Centre in Rijeka. Evoked brain potentials were measured by the visual oddball paradigm - the task of simple visual discrimination. Participants were instructed to look at a presentation of visual stimuli (a red circle in the center of the monitor) and to react by pressing the pen when seeing the target stimulus. Early and late EP-components were measured: N1, P2, N2, $\mathrm{P} 3$ and SW in two repeated blocks (interblock interval was 2 minutes). Students had their EP-measurements taken in groups of 4-6 persons, always on Wednesdays at noon (to avoid the time-of day-effect on EPs). This procedure lasted for four months. A Medelec/TECA SapphireII 4E, Vickers Medical device with five $\mathrm{Ag} / \mathrm{AgCl}$ disc electrodes was used (Sapphire ${ }^{I I}$ User Manual 003W009A, 1996). Two groups of active electrodes were applied: two occipital (O1 \& O2) and two parietal (P3 \& P4) electrodes according to the 10-20 system, and referred to by Fz. The electrode impedance was kept below $5 \mathrm{k} \Omega$ and the bandpass filter was 0.1-50 Hz. A reverse pattern of binocular full field stimulation was performed in a dark, quiet room using a 16x16 checkerboard pattern, $70 \mathrm{~cm}$ away from the nasion, with $1 \mathrm{~Hz}$ frequency and $100 \%$ contrast. In each block, 40 visual stimuli were presented to one subject, i.e. for two blocks 80 stimuli. The total number of target stimuli was 16 $(8+8)$ and non-target $64(32+32)$. The ratio of target and non-target stimuli was 16:64 (1:4). They consisted of small quadrangles, whereas the remaining ones were frequent (non-target) checkerboards that consisted of big quadrangles, presented in a random order. The rhythm of stimuli alteration was $1 / 1 \mathrm{sec}$. With the inter-stimulus interval of $1 \mathrm{sec}$, EP-measuring for one subject lasted about 5 minutes for both blocks. The storage of the measured EP-data included automatic averaging procedure and rejection of artefacts due to eye-blinks or something else ( 8 artefacts were rejected). Due to the measurements' technical limitations, EPmarking was done manually using a cursor, with baseline correction or sharpening of the EP-curve, by the same medical technician for both blocks. An example of recorded visual evoked potentials in both trials can be observed in a previous study (Tatalović Vorkapić, Tadinac, Lučev, 2013). In the first block, the marking criterion was the peak amplitude based on the defined amplitude parameters for each evoked potential. After that, the software automatically marked EPlatency. Thus, peak-to-peak amplitude and absolute latency to wave peak were marked, as seen in Figure 1. To avoid the effect of the latency jitter (Hoormann et al., 1998), and to make evoked potentials more stable over blocks, in the second block all evoked 

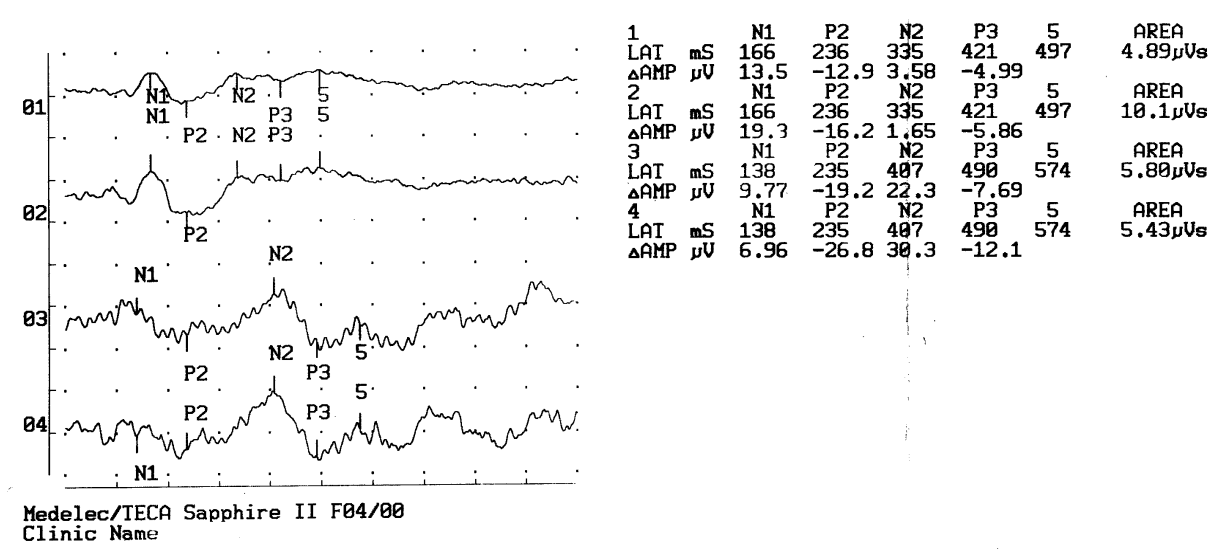

Figure 1. The example of manually marked and averaged EP-curve with all amplitudes and latencies of measured evoked potentials in the first block.

potentials were marked by the same latencies as in the first block. Therefore, EP-latencies were the same in both measurements for all subjects, while the values of EP-amplitudes were different in the two measurements. SPSS 18.0 was used to perform descriptive analysis, nonparametric correlation analysis and the Mann-Whitney $\mathrm{U}$ test.

\section{RESULTS}

Correlations of Personality Dimensions, Concordance Groups and their Relationship with Age and Year of Study

The results of correlation analysis of nine personality dimensions in subject groups of high and low concordance can be seen in Table 1. The low concordance group showed rather expected correlations between nine personality dimensions. In contrast to that, the high concordance group showed two interesting significant correla- tions, which were very different from the first group.

The first one involves a significant positive correlation between impulsivity and neuroticism, which was not determined in the first group. The second one is related to the significant negative correlation between adventurousness and strength of inhibition.

Further analyses showed a significant negative correlation between year of study and different concordance groups $\left(\mathrm{r}_{\mathrm{ho}}=-.366\right.$, $\mathrm{p}=0.01$ ), and negative but not significant between students' age and different concordance groups $\left(r_{h o}=-.258, p=0.06\right)$. In addition, a Chi-square test was run to test the difference in significance between two concordance groups, according to the year of study, and it showed a statistical significance $\left(\chi^{2}=8.140, \mathrm{df}=3,1, \mathrm{p}=.04\right)$. Figure 2 shows an increase in personality concordance while personality discordance decreases with the year of study. Moreover, Figure 3 illuminates high and low concordance groups, with respect to the nine personality dimensions. 
Table 1. Correlation matrix of nine personality dimensions: extraversion (E), neuroticism $(\mathrm{N})$, psychoticism (P), strength of excitation (SE), strength of inhibition (SI), mobility (MO), impulsiveness (IMP), adventurousness (ADV) and empathy (EMP) in two groups: high concordance (above diagonal) and low concordance (bellow diagonal)

\begin{tabular}{|c|c|c|c|c|c|c|c|c|c|}
\hline & $\mathrm{E}$ & $\mathrm{N}$ & $\mathrm{P}$ & SE & SI & $\mathrm{MO}$ & IMP & $\mathrm{ADV}$ & EMP \\
\hline $\mathrm{E}$ & & .300 & -.295 & -.183 & .273 & $.685 * *$ & $.544 *$ & .001 & .024 \\
\hline $\mathrm{N}$ & $-.534 * *$ & & .128 & -.521 & .007 & -.014 & $.806 * *$ & -.352 & -.266 \\
\hline $\mathrm{P}$ & .222 & -.129 & & .364 & .339 & .063 & .162 & -.285 & -.206 \\
\hline SE & $.516 * *$ & $-.699 * *$ & .173 & & -.026 & .409 & -.398 & .296 & .272 \\
\hline SI & .124 & $-.320 *$ & -.035 & $.402 * *$ & & .042 & .272 & $-.663^{*}$ & .082 \\
\hline MO & $.669 * *$ & $-.669 * *$ & .203 & $.722 * *$ & $.317 *$ & & .214 & .304 & .037 \\
\hline IMP & $.434 * *$ & .053 & $.367 *$ & -.088 & -.163 & .162 & & -.178 & -.286 \\
\hline ADV & $.489 * *$ & -.278 & .217 & $.497 * *$ & .141 & .390 & .158 & 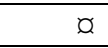 & .120 \\
\hline EMP & -.048 & $.324 *$ & $-.385 *$ & -.110 & .050 & -.169 & .094 & .015 & \\
\hline
\end{tabular}

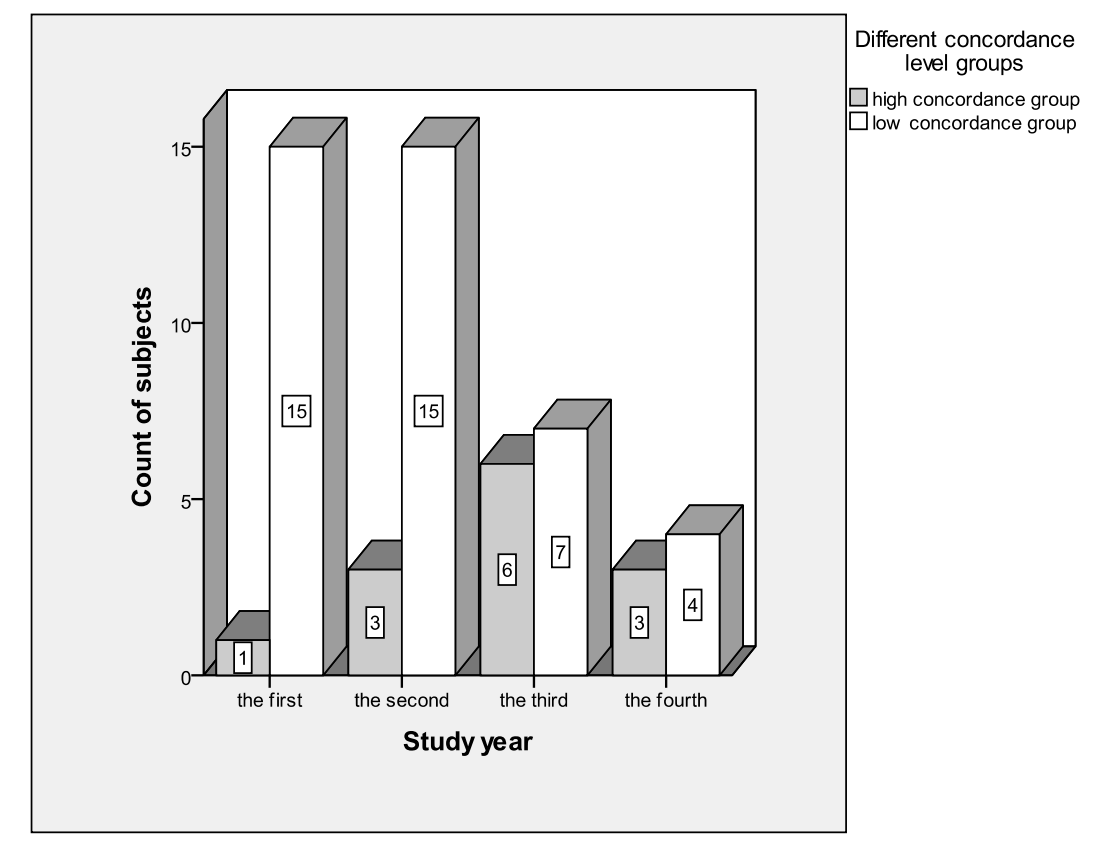

Figure 2. High and low concordance groups according to four study years 


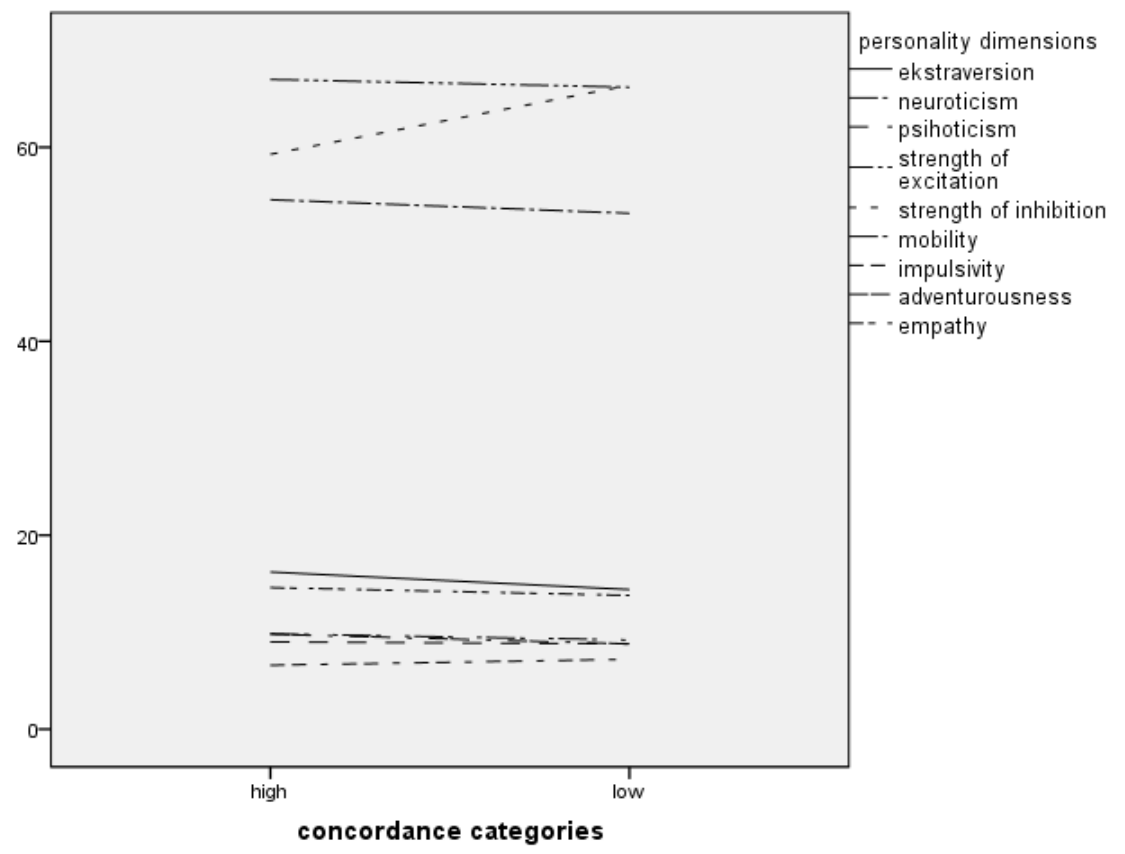

Figure 3. High and low concordance groups according to nine personality dimensions

\section{Correlation Analysis and Testing the Difference Between Groups in Personality Dimensions' Concordance and Visual Evoked Potentials}

Our correlation analysis included all measured evoked potentials on all four electrodes (two occipital and two parietal) separately and personality dimensions concordance in the two groups. This analysis revealed five significant Spearman correlation coefficients between evoked potentials and groups with personality dimensions' concordance (Table 2). N2-latencies on parietal electrodes are significantly negatively correlated with the concordance group, in which higher level of concordance is related to significant shortening of N2-latencies (Figure 4). In order to analyze the significance of the differences between these two groups in N2-latencies, means, standard deviations, means' ranks and Mann-Whitney U test results are also presented in Table 2. According to the determined results, the high concordance group showed significantly shorter N2-latencies than the low concordance group.

The amplitudes of early and late EP-components on parietal electrodes showed significant positive correlation with the concordance group, i.e. the amplitudes of the N1P2-P3 complex. In other words, with higher level of personality dimensions' concordance, we found a significantly higher level 
Table 2. Spearman's correlation coefficients of personality dimensions' concordance groups (low $=1$, high $=2$ ) and amplitudes and latencies of visual evoked potentials (zero order and partial correlations), their descriptive parameters and results of Mann-Whitney $\mathrm{U}$ test

\begin{tabular}{|c|c|c|c|c|c|}
\hline \multirow{2}{*}{$\begin{array}{l}\text { EP latencies } \\
\text { and amplitudes }\end{array}$} & \multicolumn{2}{|c|}{$\begin{array}{l}\text { Personality dimensions' } \\
\text { concordance groups }\end{array}$} & \multirow{2}{*}{$\begin{array}{l}\text { Means (standard } \\
\text { deviations) of two } \\
\text { concordance } \\
\text { groups }\end{array}$} & \multirow{2}{*}{$\begin{array}{l}\text { Means' ranks } \\
\text { of visual EPs } \\
\text { in two } \\
\text { concordance } \\
\text { groups }\end{array}$} & \multirow{2}{*}{$\begin{array}{c}\text { Mann- } \\
\text { Whitney Us } \\
\text { and } \\
\text { Significance } \\
\text { levels (p) }\end{array}$} \\
\hline & $\begin{array}{c}\text { Zero } \\
\text { order corr }\end{array}$ & Par & & & \\
\hline \multirow{2}{*}{$\begin{array}{l}\text { N2-latency on } \\
\text { P3 electrode }\end{array}$} & \multirow{2}{*}{$\begin{array}{c}\mathrm{r}_{\mathrm{ho}}=-.293 \\
(\mathrm{p}=.03)\end{array}$} & \multirow{2}{*}{$\begin{array}{c}0.192 \\
(p=0.17)\end{array}$} & 8 & & \multirow{2}{*}{$\begin{array}{l}161.00 \\
p=.03\end{array}$} \\
\hline & & & (2) 29 & & \\
\hline \multirow{2}{*}{$\begin{array}{l}\text { N2-latency on } \\
\text { P4 electrode }\end{array}$} & \multirow{2}{*}{$\begin{array}{c}\mathrm{r}_{\mathrm{ho}}=-.307 \\
(\mathrm{p}=.02)\end{array}$} & \multirow{2}{*}{$\begin{array}{c}0.196 \\
(p=0.16)\end{array}$} & (1) 26 & & \multirow{2}{*}{$\begin{array}{l}156.00 \\
p=.02\end{array}$} \\
\hline & & & (2) 298.4 & $(2$ & \\
\hline \multirow{2}{*}{$\begin{array}{l}\text { P2-amplitude } \\
\text { on P3 electrode }\end{array}$} & \multirow{2}{*}{$\begin{array}{c}\mathrm{r}_{\mathrm{ho}}=.270 \\
(\mathrm{p}=.05)\end{array}$} & \multirow{2}{*}{$\begin{array}{c}-0.122 \\
(p=0.38)\end{array}$} & (1) 1 & & \multirow{2}{*}{$\begin{array}{l}169.50 \\
p=.05\end{array}$} \\
\hline & & & (2) 7.97( & (2) & \\
\hline \multirow{2}{*}{$\begin{array}{l}\text { N1-amplitude } \\
\text { on P4 electrode }\end{array}$} & \multirow{2}{*}{$\begin{array}{l}\mathrm{r}_{\mathrm{ho}}=.285 \\
(\mathrm{p}=.04)\end{array}$} & \multirow{2}{*}{$\begin{array}{c}-0.227 \\
(p=0.10)\end{array}$} & (1) 20 . & (1) & \multirow{2}{*}{$\begin{array}{l}164.00 \\
p=.04\end{array}$} \\
\hline & & & (2) 13 & & \\
\hline \multirow{2}{*}{$\begin{array}{l}\text { P3-amplitude } \\
\text { on P4 electrode }\end{array}$} & \multirow{2}{*}{$\begin{array}{l}\mathrm{r}_{\mathrm{ho}}=.283 \\
(\mathrm{p}=.04)\end{array}$} & \multirow{2}{*}{$\begin{array}{c}-0.190 \\
(p=0.17)\end{array}$} & (1) 1 & & \multirow{2}{*}{$\begin{array}{l}164.50 \\
p=.04\end{array}$} \\
\hline & & & (2) $4.72(8.59)$ & (2) 25.01 & \\
\hline
\end{tabular}

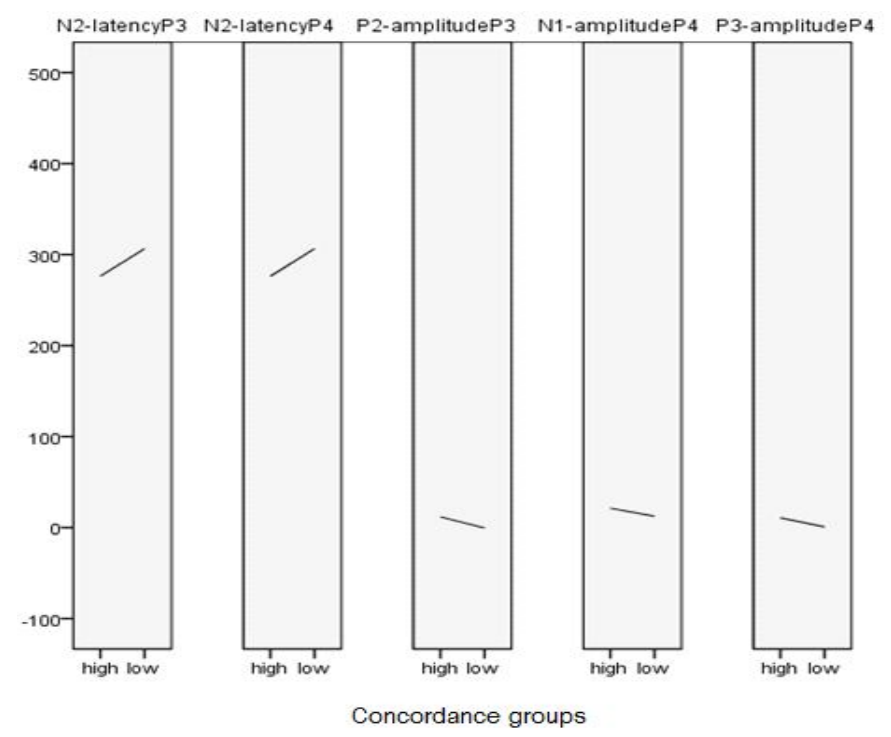

Figure 4. N2-latencies and N1-P2-P3-amplitudes on both parietal electrodes (P3 and P4) according to high and low concordance groups 
of amplitude (Figure 4). In relation to this, the high concordance group showed significantly higher N1-P2-P3 amplitudes than the low concordance group.

Finally, since prior analysis showed significant correlation between concordance groups and the year of study, partial correlations were calculated, with concordance groups and visual evoked potentials as the main variables controlling for the year of study. The findings revealed that when controlling for the year of study, there is no significant EP-concordance relationship. This is very important to emphasize, since this study objectively proved that all possible differences in visual evoked potentials between high and low personality dimensions' concordance groups are determined based on the maturation process.

\section{DISCUSSION}

\section{The Personality Dimensions Relationship within two Concordance Groups and their Relation to Age and Year of Study}

First of all, it is very important to emphasize that the number of subjects was not equalized enough (high $\mathrm{N}=13$ and low $\mathrm{N}=$ 41 concordance groups), which could present one of the limitations of this study concerning the results of interpretation. Nevertheless, since there is a lack of studies within the field of personality electrophysiology, it is important to analyze the determined findings. As explained before, with the analogy of some measures of human intelligence, such as WAIS (Crawford et al., 2012), it is expected to find significant positive correlation between personality dimensions' concordance and age due to the CNS-matu- ration processes (Dabić-Jevtić, Mikula, 1994). Thus, a significant difference was established between high and low concordance groups, where higher concordance was observed in higher years of study and vice versa. It was very important to verify the relationship between the subjects' age and concordance in any other future studies, since this relationship could coincide with other relations analyzed in research. Examining the relations between nine personality dimensions separately in high and low concordance groups, it was interesting to find that these differences have not been determined in prior studies (Chernyshev et al., 2011). In prior studies, concordant participants showed significantly higher levels of mobility, which was not the case in this study. In this study, the greatest difference between these two groups was determined in the strength of inhibition, but it was not significant.

Furthermore, the personality dimensions correlations were analyzed separately for two concordance groups. The correlation coefficients that did not reach statistical significance in the high concordance group still had the same correlation direction. They are interpreted as being similar to those in the low concordance group, due to the small number of participants in the first group. The main difference was determined in the relationship between impulsiveness and neuroticism, which was significantly positive in the first group. The second one is related to the significant negative correlation between adventurousness and strength of inhibition, again in the first group. Even though there are no studies about these specific differences, they could be explained by the fact that both dimensions, impulsivity and adventurousness, are closely related to the 
personality maturation processes, which are different in these two groups.

\section{The Relationship Between Personality Dimensions' Concordance and Visual Evoked Potentials}

Our findings showed that highly concordant subjects exhibited significantly shorter latencies than subjects from the low concordance group. N2 component occurs always when a rare and unexpected stimulus appears, and it is connected with perceiving the stimulus in the periphery of the subject's attention and reaction time. It appears around $200 \mathrm{msec}$ after the stimulus is presented and its amplitude is in reverse proportion to the probability of stimuli emersion. It shows a fronto-central distribution on the scalp. In addition, it consists of two subcomponents (N2a and N2b) and it occurs within the process of discrimination between expected and unexpected stimuli (Hugdahl, 1995). Therefore, it is reasonable to determine a significant relationship between N2-latency and personality dimensions' concordance level, based on a given task of discriminating between expected and unexpected visual stimuli. This relationship was expected, since superior performance, exhibited as faster cognitive engagement on the task operationalized as shorter EP-latencies, is related to higher performance overall. This finding is in line with the hypothesis, which is based on the results concerning neurological correlates of intelligence, where large discrepancies between verbal IQ and performance IQ are more common in neurologically impaired individuals, compared to controls (Knight, 1997). Finally, the significant correlation found between the personality dimensions' concordance level and only the latency of the N2-component, and not other EP-components, can be explained by two factors: maturation process and task difficulty level. These should be objectively analyzed in future studies.

Only measured on parietal electrodes, EPamplitudes showed significant positive correlation with concordance, i.e. amplitudes of the N1-P2-P3 complex. With higher level of personality dimensions' concordance, a significantly higher level of amplitude has been determined (Figure 4). In relation to this, the high concordance group showed significantly higher N1-P2-P3 amplitudes than the low concordance group. N1 is related to selective attention, while $\mathrm{P} 2$ is related to early information processing. Together with N1, P2 encodes the physical characteristics of stimuli. Furthermore, if a certain change in the surroundings is relevant to the given task, N2 should be followed by P3. The P3 component has been considered a cognitive component, since its main psychological correlates are attention allocation and changes in working memory (Polich, Kok, 1995). Unlike in the case of the relationship between personality dimensions' concordance and EP-latencies, these results showed a more stable relation between personality concordance and EP-amplitudes.

The determined direction of the correlation was expected, since higher EP-amplitudes are connected with higher intellectual performance and healthier psychological functioning overall. Higher level of personality dimensions' concordance is significantly related to the same variables. The only question in this study that remains unclear is as follows: Could this relationship be analyzed in the context of higher psychological functioning or is it significantly moderated by the students' year of 
study and age? This possible maturation effect on this relationship was checked by additional correlation analyses (Table 2). By comparing zero order and partial correlation coefficients, it can be seen that none of them were significant, when controlling for the students' year of study. In other words, the significant correlations found between EP latencies and amplitudes and personality dimensions' concordance level could be ascribed to the maturation process. If we want to clearly analyze the personality concordance and evoked potentials relationship, the main guideline for future research is to use student samples more homogenous by age or year of study. In this way, a valid relation between these variables could be reliably analyzed. This research only demonstrated a strong correlation between the year of study and the EP-personality concordance relationship, which puts the maturation process of personality development in the focus of the study. In addition, the described effects were determined only on parietal electrodes, due to electrode montage that favored better signal-to-noise ratio for parietal electrodes. Nevertheless, since there are a small number of similar studies, the results of measured evoked potentials on all electrodes were presented here. Thus, one of the future research guidelines could be to use various electrodes and more contemporary EP-measurements.

\section{CONCLUSION}

To summarize, the determined findings demonstrated a significant difference in latencies and amplitudes of all evoked potentials, except in the slow wave. The low concordance group showed significantly lower
N1-P2-P3-amplitudes and longer N2-latency. Significant correlation was determined between the year of study and personality concordance, where students of higher years of study showed higher levels of concordance. The determined results were analyzed and discussed in the frame of an important relationship between evoked potentials and concordance of personality dimensions, in this case as a part of ongoing maturation processes. Finally, beside the year of study effect, it is important to emphasize other limitations of this study, which should be taken into account in the future. The generalization of the results of this study is limited due to the small number of participants, not equalized number of subjects in the two concordance groups, many personality dimensions being taken into account (nine of them), a rigorous criterion of dividing groups into high and low concordance, homogeneity of the sample in personality traits, and technical limitations of the EP-measurement (electrodes choice, manual marking, etc.). On the other hand, the main contribution of this research lies in the raising the significance of measuring personality dimensions' concordance, in regards to its electrophysiological correlates.

Received May 2, 2014

\section{REFERENCES}

BeAuducel, A., BROCKe, B., LeUe, A., 2006, Energetical bases of extraversion: Effort, arousal, EEG, and performance. International Journal of Psychophysiology, 62, 212-223.

CHERNYSHEV, B.V., CHERNYSHEVA E.G., RAMENDIK, D.M., ZINCHENKO, V.P., 2011, Manifestations of temperament and perception in auditory evoked potentials. In: B. Kokinov, A. Karmiloff-Smith, N.J. Nersessian (Eds.), European Perspectives on Cognitive Science. New Bulgarian 
University Press. http://nbu.bg/cogs/eurocogsci2011/ proceedings/contents.html

CRAWFORD, J.R., GARTHWAITE, P.H., LONGMAN, R.S., BATTY, A.M., 2012, Some supplementary methods for the analysis of WAISIV index scores in neuropsychological assessment. Journal of Neuropsychology, 6, 2, 192-211.

DABIĆ-JEFTIĆ, M., MIKULA, I., 1994 , Evocirani potencijali kore mozga - Osnovne postavke i klinička primjena (Evoked brain potentials - General settings and clinical application). Školska knjiga, Zagreb.

EYSENCK, H.J., EYSENCK, M.W., 1985, Personality and individual differences: A natural science approach. New York: Plenum Press.

EYSENCK, H.J., EYSENCK, S.B.G., 1994 Priručnik za Eysenckove skale ličnosti: EPS-odrasl (Manual for Eysenck personality Scales: EPSadults). Naklada Slap, Jastrebarsko.

GURRERA, R.J., SALISBURY, D.F., O'DONNELL, B.F., NESTOR, P.G., MCCARLEY, R.W., 2005, Auditory P3 indexes personality traits and cognitive function in healthy men and women. Psychiatry Research, 133, 215-228.

HANSENNE, M., PITCHOT, W., PINTO, E., REGGERS, J., PAPART, P., ANSSEAU, M., 2000, P300 Event-related brain potential and personality in depression. European Psychiatry, 15, 1-8.

HOORMANN, J., FALKENSTEIN, M. SCHWARZENAU, P., HOHNSBEIN, J., 1998 Methods for the quantification and statistical testing of ERP differences across conditions. Behavior Research Methods, Instruments, \& Computers, 30, 1, 103-109.

HUGDAHL, K., 1995, Psychophysiology: The mind-body perspective. Harvard University Press, USA.

KNIGHT, R., 1997, The Wechsler Adult Intelligence Scale - Revised in clinical neuropsychology practice. New Zealand Journal of Psychology, 26 , $1,2-19$

LAZAREV, I.E., CHERNYSHEV, B.V., CHERNYSHEVA, E.G., OSOKINA, E.S., RAMENDIK, D.M., 2012, Influence of the concordance of temperament questionnaires data on the properties of the event-related potentials. International Journal of Psychophysiology 85, p. 388. doi:10.1016/j.ijpsycho.2012.07.070.

LEZAK, M., 1994, Neuropsychoogical testing ( $3^{r d}$ ed.). New York: Oxford University Press.

LUCK, S., 2005, An introduction to the eventrelated potential technique. Cambridge MA: MIT Press.
LUČEV, I., TADINAC BABIĆ, M., TATALOVIĆ, S., 2002, Konstrukcija hrvatske verzije Pavlovijanskog upitnika temperamenta (PTS) (Construction of the Croatian version of the Pavlovian Temperament Survey (PTS). Suvremena Psihologija, 5, 207-226.

PHILIPOVA, D.T., 2008, Changes in N1 and P3 components of the auditory event-related potentials in extroverts and introverts depending on the type of the task. Folia Medica, 50, 2, 24-31.

POLICH, J., 1993, Cognitive brain potentials. Current Directions in Psychological Science, 175179.

POLICH, J., 1998, P300 Clinical utility and control of variability. Journal of Clinical Neurophysiology, 15, 1, 14-33.

POLICH, J., KOK, A., 1995, Cognitive and biological determinants of P300: An integrative review. Biological Psychology, 41, 103-146.

RAMENDIK, D.M., 2008, The complex of cognitive and personal traits of adults as a means of adaptation and self realization. Third International Conference on Cognitive Science, 2 (pp. 434-425) Moscow: Khudozhestvennoizdatelskiy centr.

RUSALOV, V.M., 2000, Natural preconditions and individual-psychophysiological peculiarities of personality. In: Psychology of personality in works of Russian psychologists. St.-Petersburg: Piter.

SAPPHIREII USER MANUAL 003W009A, 1996, Medelec, Vickers Medical \& Teca Vickers Medical. Medical Device Directive, Medelec Ltd, England.

STELMACK, R.M., GEEN, R.G., 1992, The psychophysiology of extraversion. In: A. Gale, M.W. Eysenck (Ed.), Handbook of Individual Differences: Biological Perspectives (pp. 227-254), John Wiley \& Sons, Ltd. New York, USA

STENBERG, G., 1994, Extraversion and the P300 in a Visual Classification Task, Personality and Individual Differences, 16, 4, 543-560.

STENBERG, G., ROSEN, I., RISBERG, J., 1990, Attention, and personality in augmenting/reducing of visual evoked potentials, Personality and Individual Differences, 11, 12, 1243-1254.

STRELAU, J., 1983, Temperament, personality, activity. London: Academic Press.

STRELAU, J., ANGLEITNER, A., NEWBERRY, B.H., 1999, Pavlovian Temperament Survey (PTS): An international handbook. Göttingen: Hogrefe \& Huber Publishers.

TATALOVIĆ VORKAPIĆ, S., 2009, Biological correlates of P300 and its relationship with extra- 
version. Collegium Antropologicum, 33, 4, 1215 1222.

TATALOVIĆ VORKAPIĆ, S., 2010, Odnos između temperamenta, temeljnih dimenzija ličnosti i evociranih mozgovnih potencijala (The relationship between temperament, basic personality dimensions and evoked brain potentials). Doctoral dissertation. Faculty of Humanities and Social Sciences, University of Zagreb, Croatia.
TATALOVIĆ VORKAPIĆ, S., TADINAC, M., RUDEŽ, J., 2010, P300 and extraversion in the visual oddball paradigm. Studia Psychologica, 52, 1, 3-14.

TATALOVIĆ VORKAPIĆ, S., TADINAC, M., LUČEV, I., 2013, Electrocortical correlates of temperament. Polish Psychological Bulletin, 44, 1, $92-$ 101.

\title{
VZŤAH MEDZI ZHODOU NIEKTORÝCH OSOBNOSTNÝCH DIMENZII A ZRAKOVO EVOKOVANÝMI POTENCIÁLMI
}

\author{
S. T a t a lović Vork a pić
}

Súhrn: Štúdia skúma možné rozdiely v ERP medzi jednotlivcami s vysokou a nízkou zhodou v deviatich osobnostných dimenziách: extraverzia, neurotizmus, psychotizmus, sila vzrušenia, sila inhibície, mobilita, impulzívnost', dobrodružnost' a empatia. Na meranie skorších a neskorších EP-komponentov sme použili štandardnú zrakovú paradigmu v dvoch blokoch: N1, P2, N2, P3 a SW na vzorke $\mathrm{N}=54$ študentov psychológie (všetko ženy, priemerný vek 20 rokov). Výsledky ukázali signifikantné rozdiely v meraných ERP okrem pomalej vlny. Skupina s nízkou zhodou vykazovala signifikantne nižšie EP-amplitúdy a dlhšie EP-latencie N1, P2, N2 a P3. Tiež sme signifikantnú koreláciu zistili aj medzi študijným ročníkom a osobnostnou zhodou, kde študenti vyšších ročníkov vykazovali vyššiu zhodu. Zistenia diskutujeme v rámci dôležitých vzt’ahov medzi evokovanými potenciálmi a zhodou osobnostných dimenzií, v tomto prípade ako súčasti prebiehajúceho dospievania. 